\title{
Monitoring program for mammals in a protected area of Colombia
}

\author{
Germán Jiménez $^{1,2, *}$, Natalia López-Cepeda ${ }^{2}$, Andrea P Delgado ${ }^{2}$, Ana M Guevara ${ }^{2}$, \\ Laura Lozano ${ }^{2}$
}

Edited by

Juan Carlos Salcedo-Reyes

(salcedo.juan@javeriana.edu.co)

1. Ecology and Systematics Unit (UNESIS), Department of Biology,

Pontificia Universidad Javeriana, Bogotá

Colombia \& Centre for Research and

Studies on Biodiversity and Genetic

Resources (CIEBREG), Pereira,

Colombia.

2. Wildlife Conservation and

Management Group, Pontificia

Universidad Javeriana, Bogotá,

Colombia.

*german.jimenez@javeriana.edu.co

Received: 29-04-2016

Accepted: 30-09-2016

Published on line: 14-11-2016

\section{Citation:}

Jiménez G, López-Cepeda N, Delgado AP, Guevara AM, Lozano L. Monitoring Program for Mammals in a Protected Area of Colombia, Universitas Scientiarum, 22 (1): 9-29, 2017.

doi: 10.11144/Javeriana.SC22-1.mpfm

Funding:

COLCIENCIAS Project Grant ID

002045

Electronic supplementary material: N.A.

\begin{abstract}
Between the second semester of 2009 and the first semester of 2011, camera traps were set up in conserved and disturbed habitats in the Otún Quimbaya Flora and Fauna Sanctuary. From a sampling effort of 2,066 camera-days, 673 photographs of 157 independent events were obtained for eight species of wild mammals and a domestic one. Their activity patterns were mainly nocturnal even for those species reported as diurnal. The impact of human interference and exotic species was evident for two species: Tapirus pinchaque and Cerdocyon thous. The former was observed below its altitudinal range with activity patterns mainly crepuscular and nocturnal. The second was observed in the same habitats where domestic dogs were found, with activity patterns mainly crepuscular and nocturnal. These findings suggest that both species have altered their activity patterns. Actions must be focused on decreasing the interaction of these mammals with humans and domestic dogs.
\end{abstract}

Keywords: mammal diversity; activity patterns; vegetation cover habitats; camera traps; Otún Quimbaya.

\section{Introduction}

Information on medium- and large-sized mammals that inhabit protected areas in Colombia is increasingly necessary to promote actions aimed to their protection, both at the regional and national scales (Springer et al. 2012, Gonthier \& Castañeda 2013). Currently, the Otún Quimbaya Flora and Fauna Sanctuary (SFFOQ) has research (Arredondo 2008) and monitoring (Ramírez et al. 2008) programs as part of its management activities. This endeavour requires a comprehensive identification of mammal species and their activity patterns; however, there are no updated and extensive inventories or monitoring programs, other than a checklist of Colombian mammals (Alberico et al. 2000), presence reports of some species for the Colombian Central Andes region (Sánchez et al. 2004), as well as for the Otún river basin (Lizcano \& Cavelier 2000, Lizcano et al. 2002, Lizcano et al. 2006), and former studies not monitoring based (Morales-Jiménez, 2002, Guerrero et al. 2004). As a result, the information available for SFFOQ about diversity of mammals and their activity patterns is scarce. 
Camera traps have proven to be a valuable tool for doing inventories and monitoring programs for wildlife species (Lira-Torres \& Briones Salas 2012, Gonthier \& Castañeda 2013, Lynam et al. 2013). This technique enables the assessment of mammal species diversity in a given location, including rare and elusive ones (Osbar 1999, Jackson et al. 2005, Walker \& Novaro 2009, Ilemin \& Gürkan 2010, Castellanos 2011, Springer et al. 2012, Gonthier \& Castañeda 2013), while overcoming constraints related to cost, logistics and time (Lira-Torres \& Briones-Salas 2012, Cove et al. 2013). This approach can also help determine the mammals' activity patterns (Tobler et al. 2009, Ordeñana et al. 2010, Bridges \& Noss 2011, Lynam et al. 2013) (Lenth et al. 2008, Delgado \& Zurc 2007, Kays et al. 2009, Torres \& Prado 2010, Saito \& Koike 2013).

Additionally, monitoring mammal diversity and activity patterns is important due to the relationships of these animals with anthropogenic dynamics, as supported by evidence outside and inside protected areas affected by human presence (Ordeñana et al. 2010, Lira-Torres \& Briones-Salas 2012, Gonthier \& Castañeda 2013, Lynam et al. 2013), in agriculture lands near forests (Cove et al. 2013), in interfaces between rural and urban areas (Abi Said \& Amr 2012, Saito \& Koike 2013), as well as in relation with the presence of exotic species (Ordeñana et al. 2010, Lenth et al. 2008). Therefore, monitoring species community diversity and activity patterns are fundamental aspects when evaluating species vulnerability within a protected area.

This is a key aspect in those areas where the interface between well-conserved habitat of protected forest covers and less-conserved habitat with the anthropic occupation show different levels of disturbance. This evidence is essential to predict changes in populations and communities in space and time, as well as to identify the threats they face (Salom-Pérez et al. 2007, Ordeñana et al. 2010, Sathyakumar et al. 2011, Gonthier \& Castañeda 2013, Saito \& Koike 2013), in order to implement timely and appropriate management actions (Sathyakumar et al. 2011, Lira-Torres \& BrionesSalas 2012, Saito \& Koike 2013).

Our study was aimed to monitor mammals with the use of camera traps, in order to confirm the presence of and large and medium mammals (weight $>1 \mathrm{~kg}$; Tobler et al. 2008), to estimate their numbers and to identify their activity patterns in two habitats in the SFFOQ. This information is crucial for the proposal of management actions considering the size of this protected area.

\section{Materials and Methods}

The SFFOQ $\left(4^{\circ} 43^{\prime} 42.08^{\prime \prime} \mathrm{N}-75^{\circ} 34^{\prime} 38.77^{\prime \prime} \mathrm{W}\right)$ is a National Protected Area of approximately $410 \mathrm{ha}$, located $16 \mathrm{~km}$ from Pereira, in the Department of Risaralda, on the western slope of the Colombian Central Andes, in a region known as the Colombian coffee-growing area. Ecologically, it lies between sub-Andean and Andean forests with altitudes ranging from 1,750 to $2,250 \mathrm{~m}$. The average temperature is $17{ }^{\circ} \mathrm{C}$ and average precipitation is $2,638 \mathrm{~mm}$ (Parques Nacionales, 2007). The surface of the SFFOQ is predominantly mountainous, with numerous wetlands and waterways, including the upper basin of the Otún River. Vegetation cover is comprised of two distinct groups of secondary forests: unaltered old forests and natural secondary forests. Vegetation structure and composition is the result of forest clear-cutting for cattle grazing purposes. Natural secondary forests may border with 
areas of open grasslands, patches of oak woods and in some cases, main roads. Areas around these natural secondary forests have been used to grow exotic species such as urapán (Fraxinus chinensis), a tree established more than 20 years ago, and other plants like the Colombian oak (Quercus humboldtii). It is in these areas of the SFFOQ where anthropic occupation is prevalent. Regenerating vegetation is predominant in these areas including alien species such as the white ginger lily (Hedychium coronarium) (Guerrero et al. 2004, Parques Nacionales, 2007). Areas with secondary, urapán and Colombian oak forests offer well-conserved habitats, while areas where regenerating vegetation is associated to anthropogenic occupation, offer less-conserved habitats. The Colombian mammal inventory (Alberico et al. 2000) and the Management Plan for the SFFOQ (Guerrero et al. 2004) report 30 small, medium and large mammal species, excluding bats. Some of these mammal reports are based on observations not linked to a monitoring or management plan, or to any conservation action.

Data collection: Between the second semester of 2009 and the first semester of 2011, camera trap stations were installed in different vegetation covers: Secondary Forest (SF) (young growth; 9 cameras), Urapan Forest (UF; 1 camera) and Colombian Oak Forest (OF; 1 camera), considered well-conserved habitat, as well as in Regenerating vegetation Field area (RvFa; 2 cameras) and vegetation Compost area (RvCo; 1 camera), considered less-conserved habitat (Figure 1). Each camera trap station was equipped with a passive motion sensor WILDVIEW ${ }^{\circledR}$ Infrared Xtreme camera, 1 GB $\mathrm{SD}$ memory, and a $12 \mathrm{~V}$ portable battery, located $50 \mathrm{~cm}$ above ground with a 10 -degree inclination according to manufacturer's recommendations, and programmed to shoot a maximum of six photographs, in order to increase the capture of species images. Sampling was carried out for 49 days in 2009-2 (July-December), 60 days in 2010-1 (January-June), 30 days in 2010-2 (July-December) and 30 days in 2011-1 (JanuaryJune). During 2009-2 and 2010-1 a total of 14 camera trap stations were active (9 SF, $1 \mathrm{UF}, 1 \mathrm{OF}, 2 \mathrm{RvFa}, 1 \mathrm{RvCo})$; during 2010-2 a total of 11 camera trap stations were active (7 SF, $1 \mathrm{UF}, 1 \mathrm{OF}, 1 \mathrm{RvFa}, 1 \mathrm{RvCo}$ ), and in 2011-1 a total of seven camera trap stations were active ( $3 \mathrm{SF}, 1 \mathrm{UF}, 1 \mathrm{OF}, 1 \mathrm{RvFa}, 1 \mathrm{RvCo}$ ). During sampling periods, cameras were active $24 \mathrm{~h}$ and were checked every five to seven days to collect data and verify their correct operation. Sampling effort was calculated as the number of camera trap stations per number of sampling days, following Srbek-Araújo \& Chiarello (2005).

Data analysis: the data of each photograph were processed using the open access software Camera Base version 1.4 (Tobler 2010) because of its convenience for sorting and processing the data, while these are downloaded. Photographs 1) taken on the same date with 30-minute time intervals, and 2) taken at the same hour and date for different individuals of the same species and for different individuals of different species, were considered independent events following Yasuda, (2004), MonroyVilchis et al. (2010), Abi-Said \& Amr (2012), and Lira-Torres \& Briones-Salas (2012). After randomizing the sample 1,000 times, independent events were used to calculate the species accumulation curve following Melo et al. (2012). In the curve, the addition of new species was a function of the number of sampling days per active camera between the second semester of 2009 and the first semester of 2011. We calculated the number of observed species (Sobs Mao Tau), the number of expected species (CI Upper Bound and CI Lower Bound $95 \%$ ) and the non-parametric estimators for expected species richness (Chao 1 Mean and Jack 1 Mean). These analyses were performed using open access software EstimateS version 7.52 (Colwell 2009). 


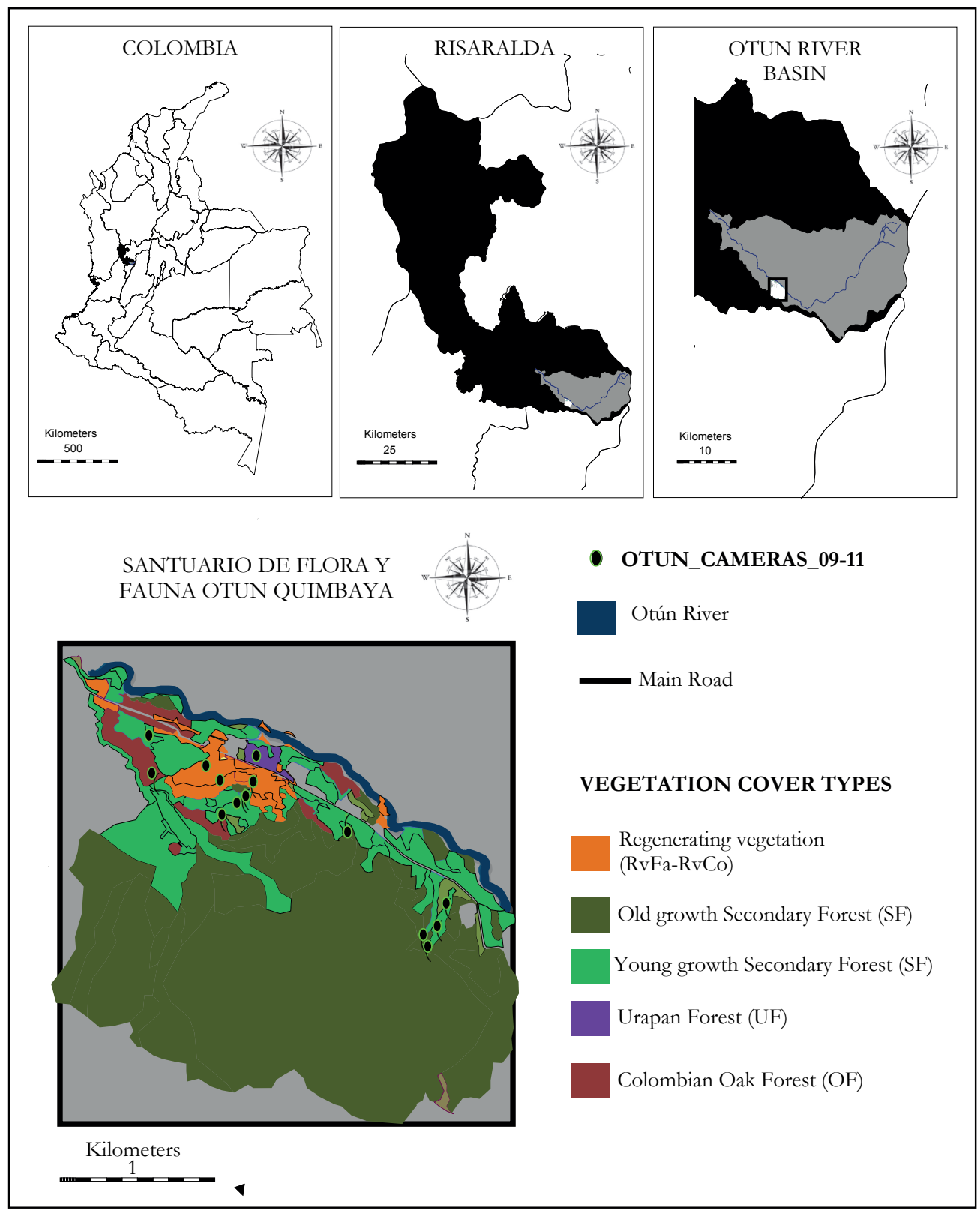

Fig. 1. Location of camera traps in the Otún Quimbaya Flora and Fauna Sanctuary, Risaralda, Colombia. Sources: SIG CIEBREG, ArcGIS 9.3, Datum D_MAGNA.

For every species with 10 or more independent events $(\geq 10)$, as well as those with between 5 and 10 independent events, and in any IUCN category of risk, we recorded their activity patterns whether crepuscular, diurnal or nocturnal, for each $24 \mathrm{~h}$ cycle following methodologies of Tobler et al. (2009), Ordeñana et al. (2010), Bridges \& Noss (2011), Lira-Torres \& Briones-Salas (2012), Lynam et al. 2013, Ramesh et al. (2013). Independent events of species observation and species activity patterns were analysed using Statgraphics Centurion XVI (StatPoint Technologies 2012). Additionally, for activity patterns, circular statistical tests were performed in Oriana 4.02 (Kovach 2011) to find differences between crepuscular, diurnal and nocturnal 
activity patterns, as well as an average hour of peak activity patterns following PérezIrineo \& Santos-Moreno (2014) and Gessner et al. (2013). To do this, photographs were plotted on a circular scale with 24 hourly sections, with the total length of the circular axis representing a day.

Table 1. Species recorded for the SFFOQ by camera traps, between the second semester of 2009 and first semester of 2011. The IUCN categories for Colombia are Least Concern (LC), Near Threatened (NT), Vulnerable (VU), and Endangered (EN). Species of High Conservation Value by SFFOQ rangers were classified as HCV. Number of asterisks indicates a higher level of risk.

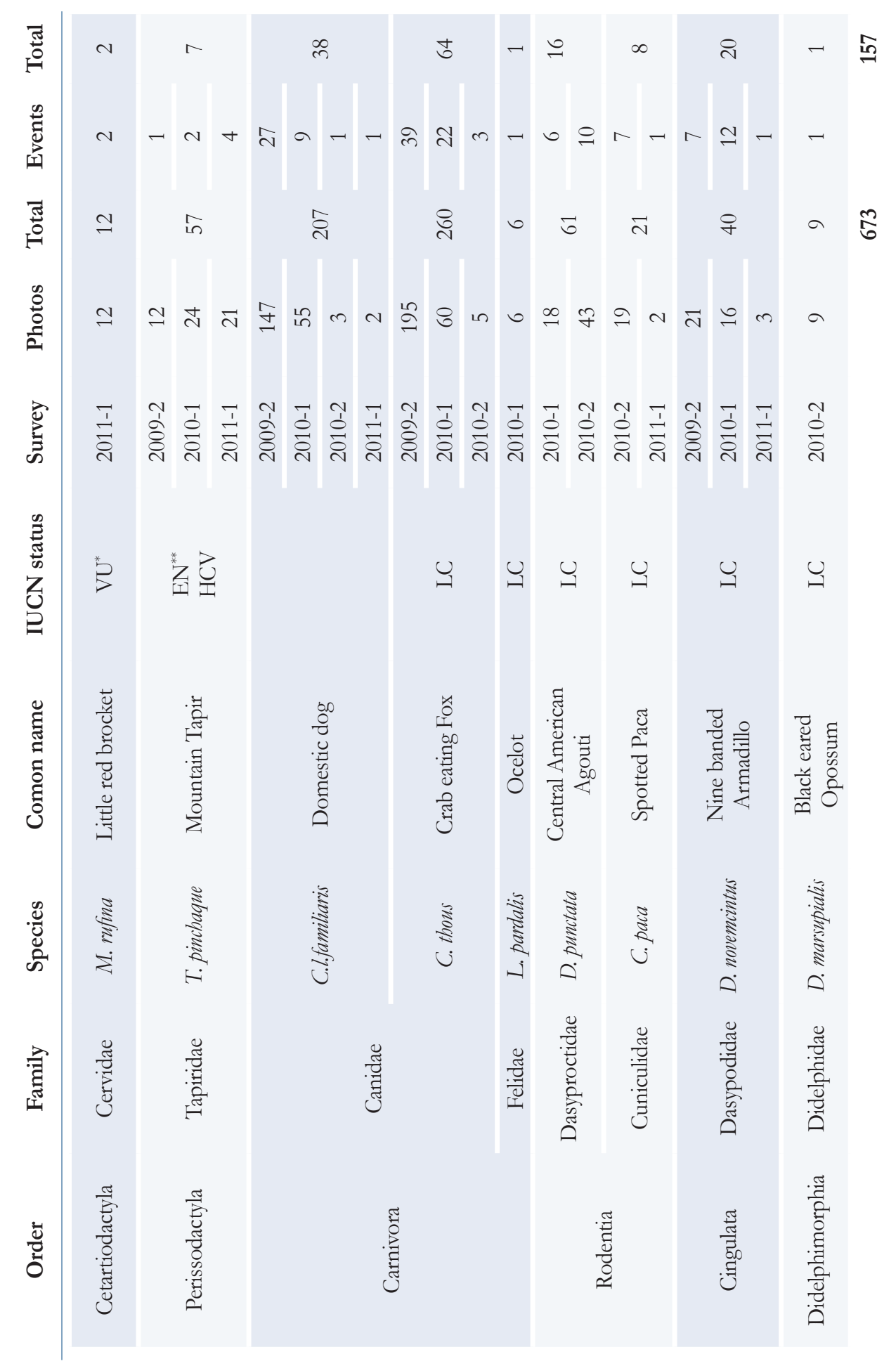




\section{Results}

Presence and number of species: A total of 466 photographs of 119 independent events were obtained for eight large $(>10 \mathrm{~kg})$ and medium-sized $(>1 \mathrm{~kg})$ wild mammal species. Additionally, 207 photographs of 38 independent events were recorded for domestic dogs (Canis lupus familiaris). Three species were recorded in 2009-2 (Cerdocyon thous, Dasypus novemcinctus, Tapirus pinchaque), five in 2010-1 (Dasyprocta punctata, Leopardus pardalis, C. thous, D. novemcinctus T. pinchaque), four in 2010-2 (Cuniculus paca, Didelphis marsupialis, C. thous, D. punctata), and four in 2011-1 (Mazama rufina, C. paca, D. novemcinctus, T. pinchaque). Canis lupus familiaris was observed in the four surveys with a high number of photographs (Table 1).

The total effort was 2,066 camera days. The species accumulation curve showed that the number of wild mammal species represented $73 \%$ of the calculated local diversity (Figure 2). Nevertheless, when it is compared with that reported by Alberico et al. (2000) for this region it is only $42 \%$ of it, as well as $44 \%$ of that listed in the SFFOQ Management Plan (Guerrero et al. 2004) (Table 2). The five wild species with most photographic records during the study were C. thous, C. paca, D. novemcinctus, $D$. punctata and, notoriously for SFFOQ, T. pinchaque (Figure 3). Three additional wild species were recorded (L. pardalis, M. rufina, D. marsupialis) but with a low number of photographs as well as independent events (less than 5). Of the total species reported, two are in some category of risk according to the Red Book of Colombian Mammals (Rodríguez-Mahecha et al. 2006); one species is considered of high conservation value (HCV) for the SFFOQ (Guerrero et al. 2004); and C. paca was identified as such by its morphological characteristics instead of as C. taczanowskii (Bonilla-Morales et al. 2013) (Figure 4).

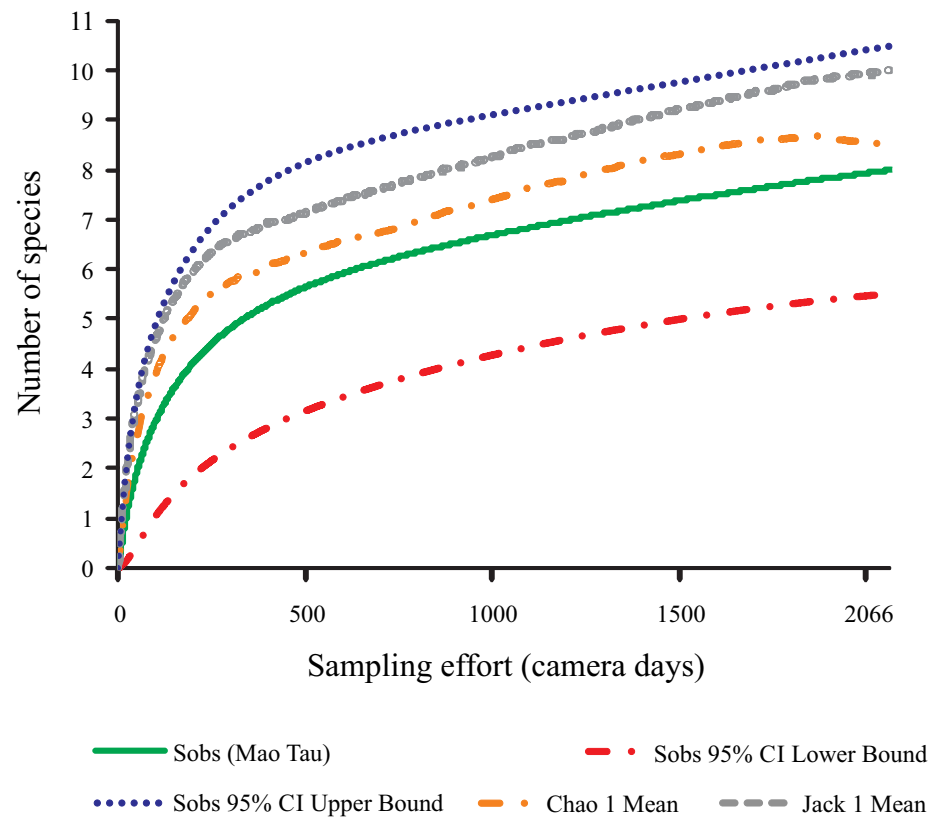

Fig. 2. Accumulation curve of wild mammal species for a sampling effort of 2,066 camera days between the second semester of 2009 and the first semester of 2011, in the SFFOQ. Number of observed species (Sobs Mao Tau), expected species, upper and lower bounds (CI Upper Bound and CI Lower Bound) and non-parametric estimators of expected species richness (Chao 1 Mean and Jack 1 Mean). 
Table 2. Large- and medium-sized mammal species ( $>1 \mathrm{~kg}$ ) reported for the Otún river basin and the western slope of the Central Colombian Andes; Department of Caldas (Alberico et al. 2000), as well as by locality (Sánchez et al. 2004, Guerrero et al. 2004, present study 2009-2011). ND = No data.

\begin{tabular}{|c|c|c|c|c|}
\hline Species & $\frac{\text { Alberico }}{\text { et al. } 2000}$ & $\begin{array}{l}\text { Sánchez } \\
\text { et al. } 2004\end{array}$ & $\frac{\text { Guerrero }}{\text { et al. } 2004}$ & $\begin{array}{c}\text { Present study } \\
\text { 2009-2011 }\end{array}$ \\
\hline Cabassous centralis & + & $\mathrm{ND}$ & + & ND \\
\hline Cerdocyon thous & + & ND & + & + \\
\hline Cuniculus paca & + & ND & ND & + \\
\hline $\begin{array}{l}\text { Cuniculus } \\
\text { taczanowskii }\end{array}$ & + & + & + & ND \\
\hline Dasyprocta punctata & + & ND & + & + \\
\hline Dasypus novemcinctus & + & + & + & + \\
\hline Didelphis albiventris & + & ND & + & ND \\
\hline Didelphis marsupialis & + & ND & + & + \\
\hline Dinomys branikii & + & + & + & ND \\
\hline Eira barbara & + & ND & + & ND \\
\hline Leopardus pardalis & + & + & + & + \\
\hline Mazama rufina & + & + & + & + \\
\hline Nasua nasua & + & + & + & ND \\
\hline Nasuella olivacea & + & + & + & ND \\
\hline Puma concolor & + & ND & + & $\mathrm{ND}$ \\
\hline Puma yagouaroundi & + & ND & + & ND \\
\hline Sylvilagus brasiliensis & + & + & + & ND \\
\hline Tapirus pinchaque & + & ND & + & + \\
\hline Tremarctos ornatus & + & ND & + & ND \\
\hline
\end{tabular}

Activity patterns: Activity patterns were recorded for C. l. familiaris, C. thous, C. paca, D. novemcinctus, D. punctata and T. pinchaque. Canis l. familiaris presented activity mainly between 15:00 and 3:00 hours, with an activity peak near 21:00 hours. Cerdocyon thous presented activity mainly between 18:00 and 0:00 hours, with an activity peak near 01:00 hours, similar to C. l. familiaris (Figure 5). Cuniculus paca had periods of activity in the early morning and at night, with an activity peak just after 22:00 hours. Dasypus novemcinctus was recorded between 19:00 and 03:00 hours, with an activity peak near 23:00 hours. Dasyprocta punctata was recorded between 06:00 and 18:00 hours, with an activity peak near 16:00 hours. Tapirus pinchaque was active mainly between 18:00 and 03:00 with an activity peak near 21:00 hours (Figure 6). Only C. l. familiaris ( $\mathrm{p}=0.00)$, C. thous $(\mathrm{p}=0.00)$, D. novemcinctus $(\mathrm{p}=0.00)$, D. punctata $(\mathrm{p}=0.03)$, and T. pinchaque $(\mathrm{p}=0.02)$ showed statistical differences between activity patterns. Canis l. familiaris was 


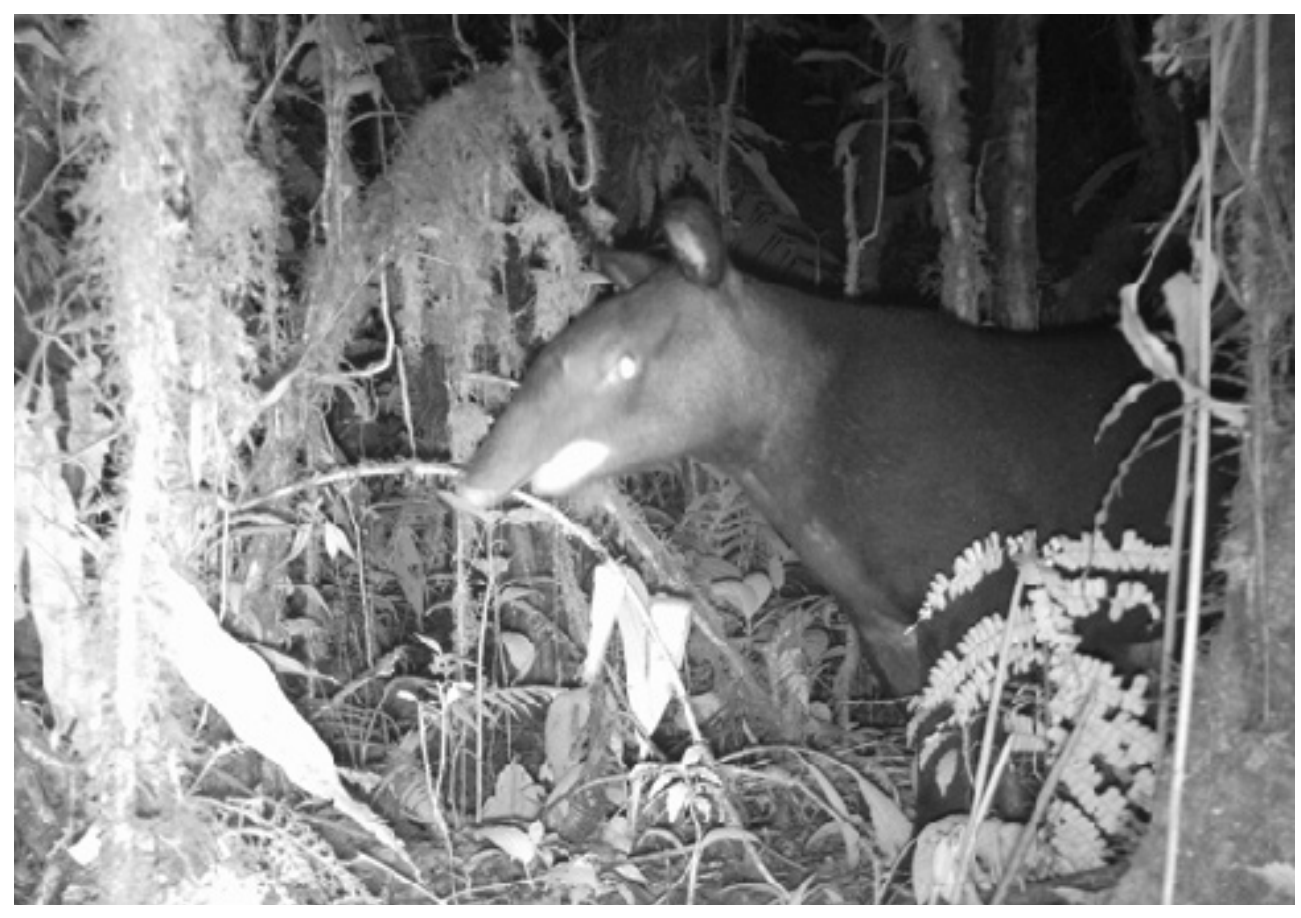

Fig. 3. Photograph for the positive identification of Tapirus pinchaque within vegetation covers of SFFOQ.

crepuscular and nocturnal, C. thous was crepuscular and nocturnal, D. novemcinctus was nocturnal, D. punctata was crepuscular and diurnal, and T. pinchaque was crepuscular and nocturnal. Cuniculus paca showed no statistical differences $(\mathrm{p}=0.08)$ and was not reported as diurnal, crepuscular or nocturnal (Figure 7).

\section{Discussion}

Presence and number of species: We reached a species diversity percentage of $73 \%$, which is higher than other studies, probably because the estimated curve is a statistical average of species aggregation based on observed species (Colwell 2009). According to the expected species richness estimators and the observed species number, peak richness values are expected at about eleven species. In 2011, despite a reduction of $50 \%$ in the number of cameras due to malfunction, four of the total eight wild species as well as C. l. familiaris were reported. After nearly 200 days of sampling, the curve grew and the upper limit for the observed species revealed that the capture effort must be increased. This finding agrees with that of Tobler et al. (2008) who found that regarding the effectiveness of camera trap inventories, a $70 \%$ of community richness is attained with 1,000 to 2,000 camera days when sampling in an area of $50 \mathrm{~km}^{2}$. With this effort we recorded $42 \%$ of species reported by Alberico et al. (2000) for this region, $44 \%$ of those listed in the SFFOQ Management Plan (Guerrero et al. 2004) as well as five species not reported by Sánchez et al. (2004) for the Central Andes. Reports of C. l. familiaris were related with human presence near SFFOQ and are due to people keeping dogs as pets thus violating rules established 


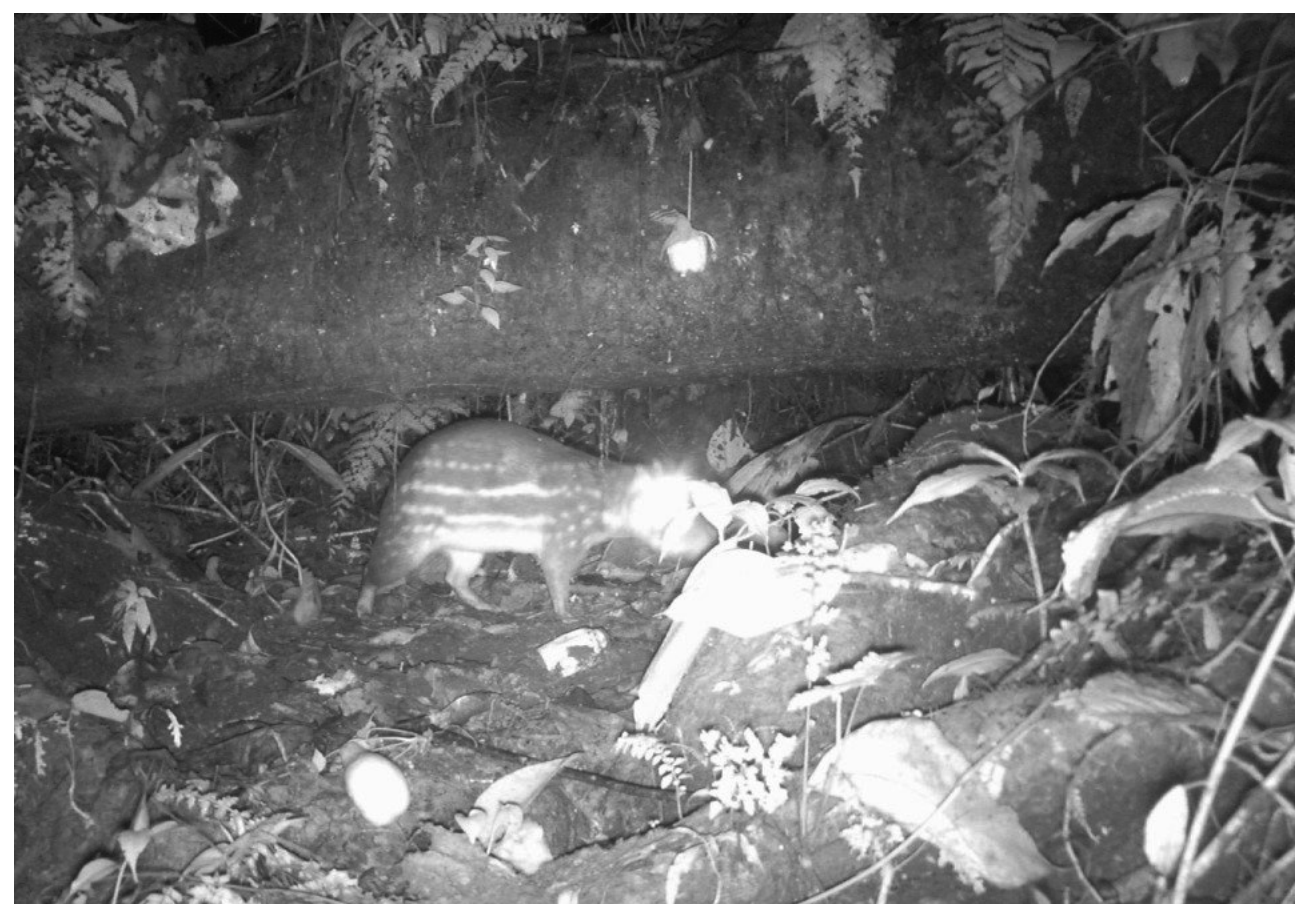

Fig. 4. Photograph for the positive identification of Cuniculus paca based on the stripe pattern of the animal's flank. Description based in Bonilla-Morales et al. (2013).

by National Parks Authority. Dog presence represents a big issue since they prey native mammals and are disease carriers.

The low densities of other species compared with data reported for SFFOQ by Alberico et al. (2000) and Guerrero et al. (2004) could be attributed to various reasons like their wide habitat range, inaccurate identification by protected area rangers, very specific habitat requirements, arboreal or aerial locomotion, size smaller than $1 \mathrm{~kg}$, and finally the sampling design and the area covered.

Authors like Laundré \& Hernández (2009) and Walker \& Novaro (2009) for Puma concolor, Castellanos (2011) for Tremarctos ornatus, and Michalski et al. (2006) and Springer et al. (2012) for Puma yagouaroundi report that these species have wide habitat ranges. The SFFOQ could be an area frequented by them in their wide movements, making their densities naturally low. However, two noteworthy species were found: T. pinchaque and L. pardalis, species with wide habitat ranges as reported for the former by Lizcano \& Cavelier (2000) and for the latter by Springer et al. (2012). Additionally, for T. pinchaque there is evidence that its movements are a response to human presence in Parque Regional Ucumarí (PRU), an area near SFFOQ where it has been reported frequently (Lizcano \& Cavelier 2000). This study shows that T. pinchaque remains constant since 2009 and frequents SF covers in SFFOQ.

In the case of inaccurate identification by protected area rangers, C. paca is not reported in the SFFOQ Management Plan (Guerrero et al. 2004) or by Sanchez et al. (2004). Instead, they report C. taczanowskii, an inaccuracy that may have occurred 
A

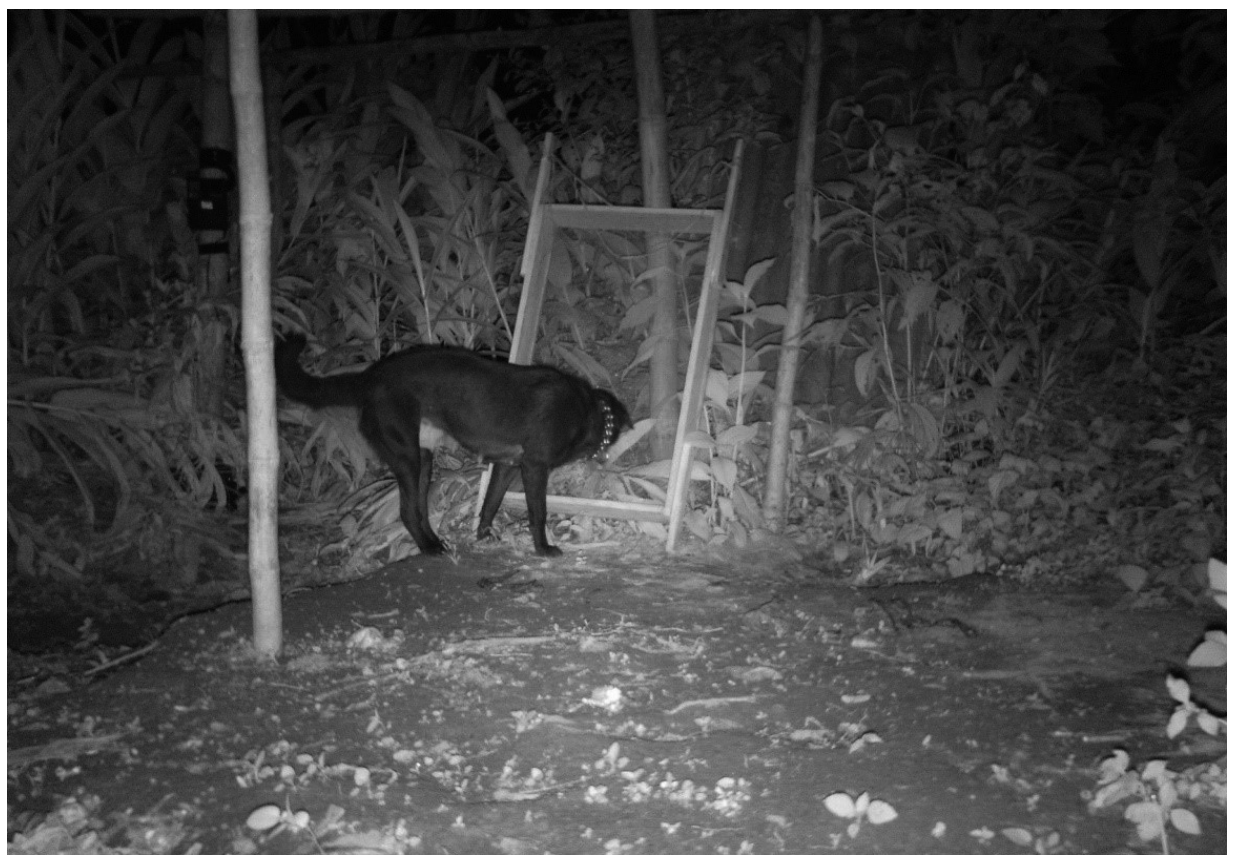

B

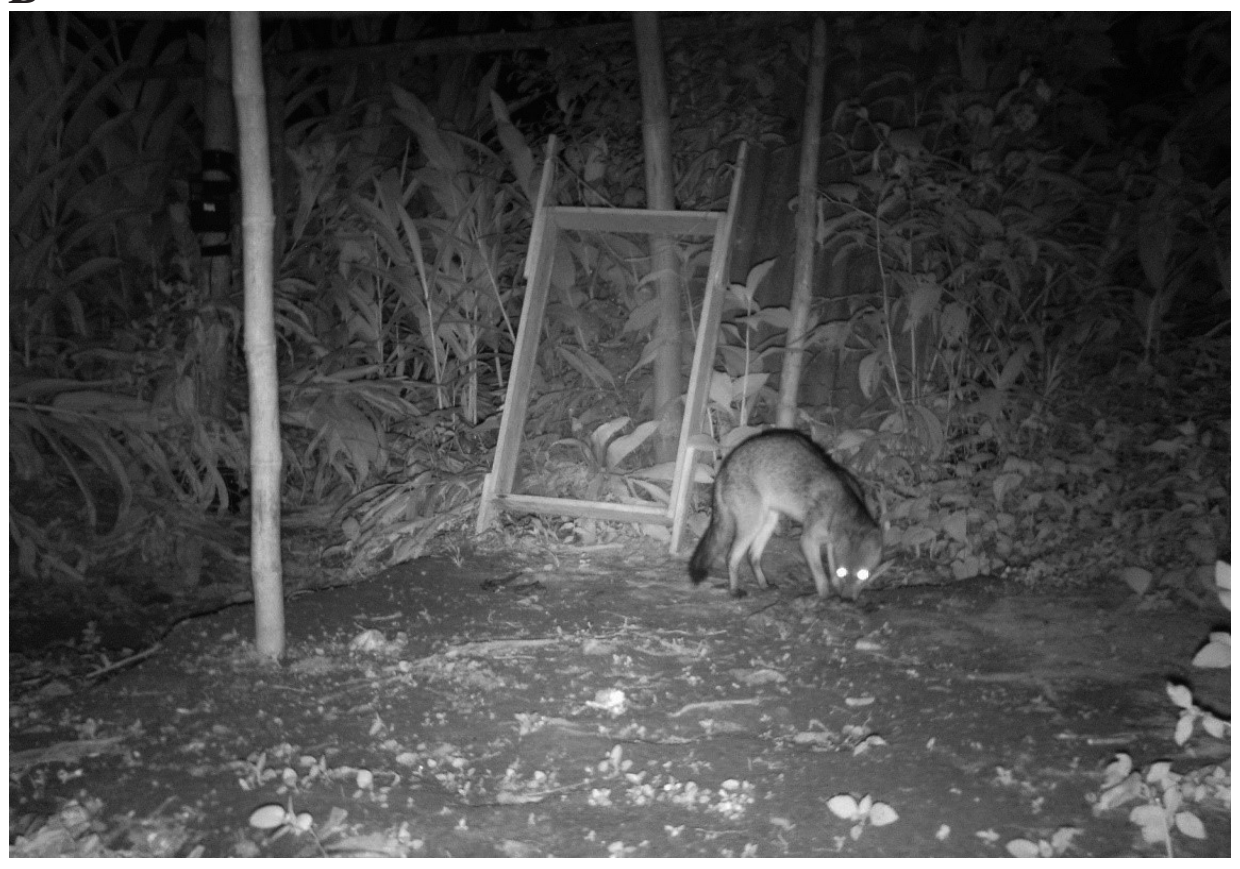

Fig. 5. Photographs revealing use of the same vegetation cover on the same date but at different day times by species A) Canis lupus familiaris and B) Cerdocyon thous.

because of the similarity in their altitude range and their overlapping zones. This and the fact that rangers do not recognize very well their morphological characteristics (fur with 3 to 5 rows of several white spots, more than $C$. taczanowskir), cause inaccurate identifications. Record evidence helps to confirm that it is actually $C$. paca and not 


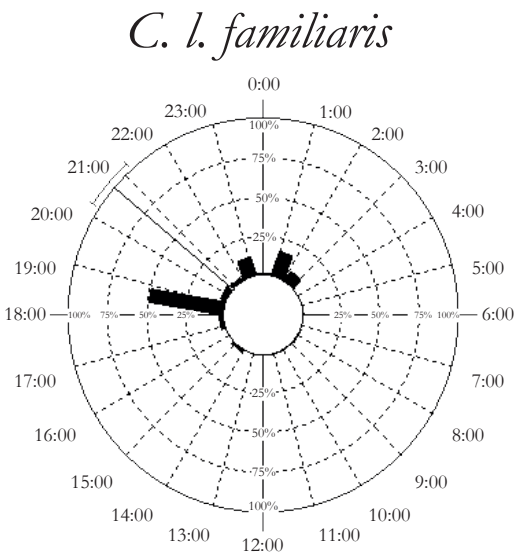

C. paca

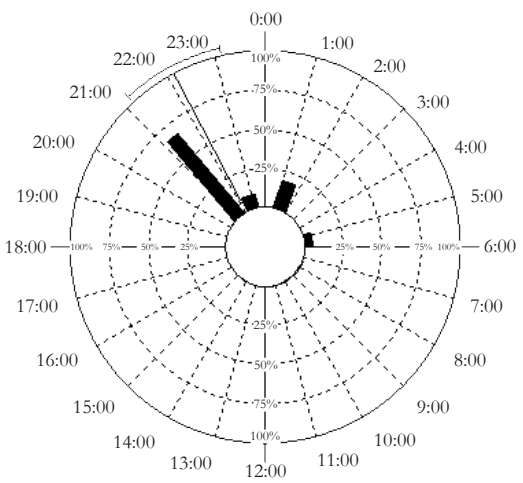

\section{D. punctata}

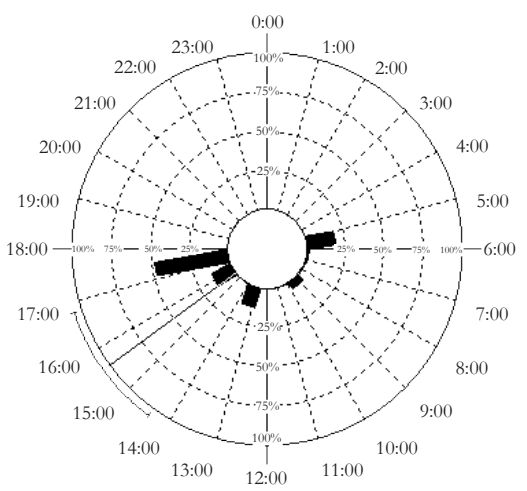

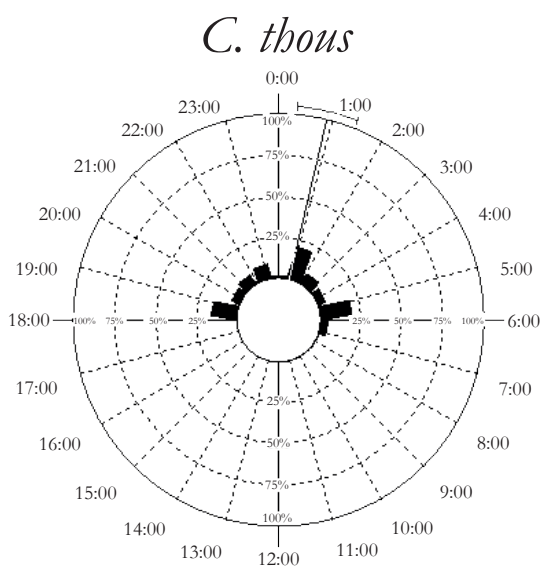

D. novemcinctus

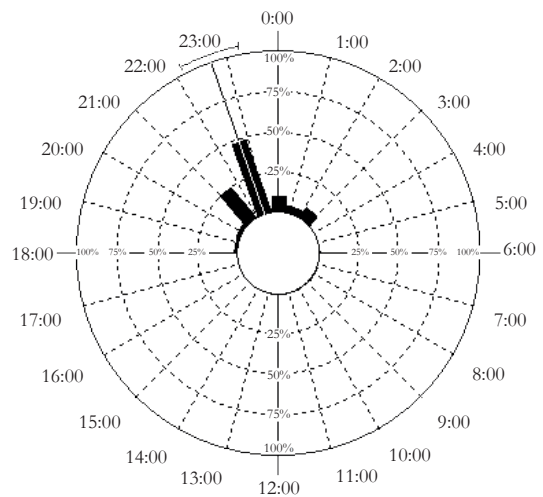

T. pinchaque

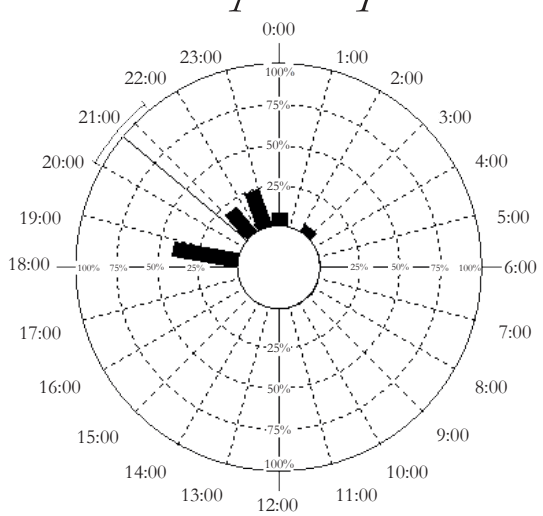

Fig. 6. Circular histograms illustrating activity patterns per 24-hour cycle, between the second semester of 2009 and the first semester of 2011 in SFFOQ for six mammal species (five wild and a domestic one). The bars represent a percentage of records per hour of the day. Vector and arc of each graph represent confidence intervals $(95 \%)$ per average hour of activity peak.

C. taczanowskii (Bonilla-Morales et al. 2013). Another species not reported here was Dinomys branickii, despite an observation made of an individual struck by a car on the main road near the SFFOQ in 2010. The SFFOQ is possibly the elevation limit of $D$. branickii distribution. Findings by Sánchez et al. (2004) support this idea; they 
A. C. l. familiaris

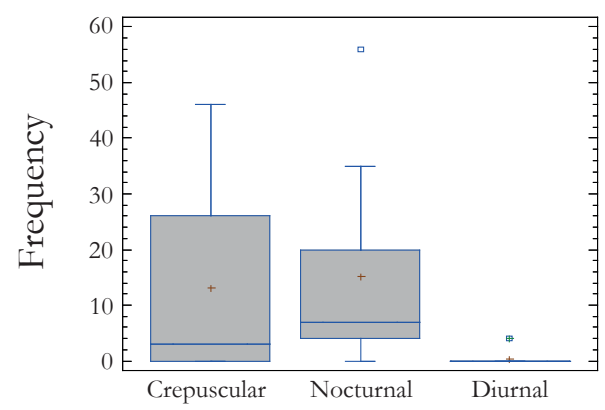

Activity Patterns

C. C.paca

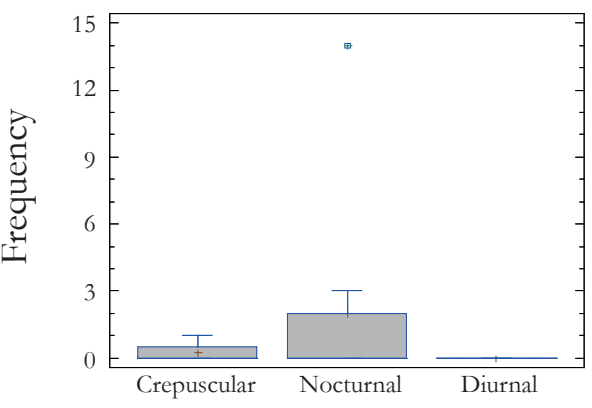

Activity Patterns

E. T. pinchaque

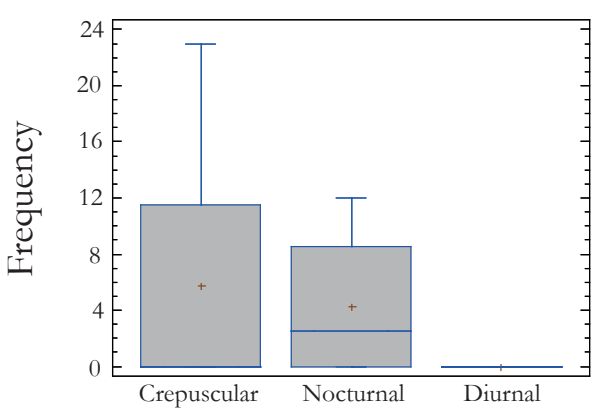

Activity Patterns
B. C. thous

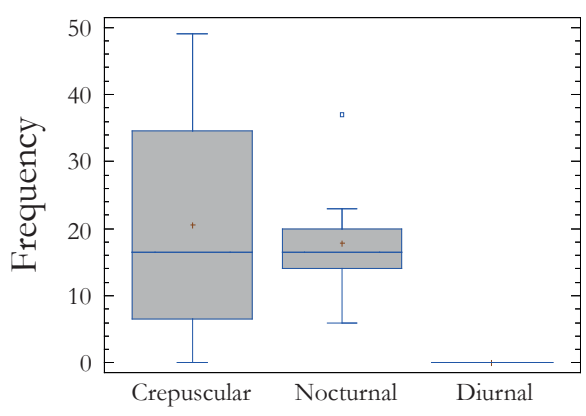

Activity Patterns

D. D. punctata

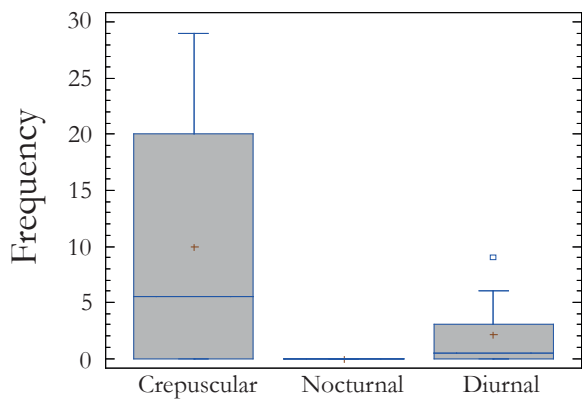

Activity Patterns

F. D. novemcinctus

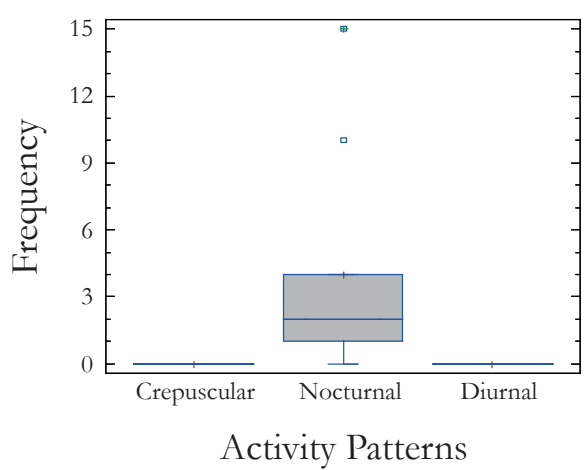

Fig. 7. Kruskal-Wallis test showing differences in frequency of activity patterns for A) C. l. familiaris, B) C. thous, C) C. paca, D) D. punctata, E) T. pinchaque and F) D. novemcinctus between the second semester of 2009 and first semester 2011 in the SFFOQ.

recorded D. branickii at altitudes between 2200 and $3750 \mathrm{~m}$ in a location in the Department of Caldas, on the same side of the cordillera and near to the area of this study. Additionally, the SF cover in SFFOQ provides plant species such as Cordia cylindrostachya, Quercus bumboldtii, Juglans neotropica and Sida rombipholia, four of the fifteen 
plant species that comprise its diet (Osbahr, 1999). These two evidences support the fact of rarely seen individuals of this species here. In relation to arboreal or aerial locomotion, or sizes smaller than $1 \mathrm{~kg}$, the only species with these characteristics reported in our study was Didelphis marsupialis, which is common in these kinds of plant covers. Related to this camera trap is not a very good method for sampling smaller species (Srbek-Araujo \& Chiarello 2005).

Finally, the sampling design and the area covered probably affected the results. Melo et al. (2012) concluded that increasing the sampling area and including a greater number of plant covers would attain a better estimate of species diversity. In this study, the SFFOQ area is small compared with those of other studies, especially for the detection of species with wide range and specific habits. Malfunction of $50 \%$ of the cameras due to weather conditions as well as the size of the study area may have caused some species to remain undetected despite the intensive sampling effort, as it happened to Lira-Torres \& Briones-Salas (2012). They covered approximately $30 \%$ of a protected area with plant covers in good conservation status. In our study, 140 ha were covered representing $38 \%$ of the SFFOQ.

Activity patterns: Nocturnal and crepuscular activity patterns of $C$. thous showed consistency in their occurrence in areas where human and C. l. familiaris presence were more constant. As seen in pictures in this study, they found many food waste resources, different from its natural diet. As an omnivorous species, it can eat small rodents and marsupials as well as plant seeds (Macdonald \& Sillero-Zubiri 2004, Delgado \& Zurc 2007, Rocha et al. 2008) and, when available, they forage food waste (e.g. composting in $\mathrm{RvCo}$ ). The same opportunistic behaviour was observed by AbiSaid \& Amr (2012) in red foxes (Vulpes vulpes). This canid genus, similar to Cerdocyon and widely distributed in Europe and North America, showed that it can combine food waste with its natural diet. Saito \& Koike (2013) noted the same behaviour in carnivores and omnivores in urban areas associated with forests in Tokyo (Japan). Additionally, abundant records of $C$. thous are evidence of its gregarious and stable relationships too (Ralls et al. 2001). These canids generally find permanent mates and remain in habitats that offer good resources. Once their offspring reach adulthood they return to the same place, as noted by Macdonald \& Sillero-Zubiri (2004).

Like other canid genera, they can tolerate human presence as found by Ordeñana et al. (2010) for coyotes (Canis latrans) and by Abi-Said \& Amr (2012) for red foxes (Vulpes vulpes). In the case of species such as $C$. thous and canids in general, Lenth et al. (2008), Torres \& Prado (2010), as well as Abi-Said \& Amr (2012) agree that these species change their habits from diurnal to nocturnal as a result of pressures generated by human settlements and the introduction of exotic species. Both of these pressures exist in the SFFOQ; there is the presence of human settlements, and the confirmed presence of exotic species such as C. l. familiaris, which had crepuscular and nocturnal habits, causing interference or maybe competition for resources with $C$. thous. During the time of the study, C. l. familiaris showed high activity patterns that clearly generate interference with activity patterns of C.thous, probably causing alterations in its behaviour. This idea is supported by Lenth et al. (2008), who detected levels of alteration in activity patterns caused by domestic dogs over species like grey foxes (Urocyon cinereoargenteus). Sime (1999) warns about the negative effect of C. l. familiaris on foxes in general and Ordeñana et al. (2010) found that where human activity is 
concentrated, other carnivores were displaced. Additional evidence suggests that the same occurs with other mammal groups such as small wildcats, which are forced to modify their nocturnal activity patterns in areas subjected to human pressure (Lynam et al. 2013).

This study reports T. pinchaque individuals below the Ucumarí Regional Park, where this species has been observed most frequently. There are no permanent records of this species in the SFFOQ before 2009; records in our study persisted until 2011. Lizcano \& Cavelier (2000) and Lizcano et al. (2002) reported this species at altitudes of 2,000 $\mathrm{m}$ and higher, with activity patterns diurnal and nocturnal, but mostly nocturnal when exposed to human presence (Lizcano et al. 2006). In our study, T. pinchaque was observed mostly late at night and was significantly crepuscular and nocturnal. The photographs of this species within the SFFOQ obtained during the sampling period were atypical and may indicate a shift of this mammal to the SFFOQ, as a consequence of human presence. Lizcano \& Cavelier (2000) support this assertion; they indicate a movement of tapirs from paramo (a high Andean ecosystem) towards lower altitudes, stimulated by the development of farming and livestock grazing areas associated with human settlements. Carbajal-Borges et al. (2014) confirmed the influence of anthropic intervention on the activity patterns of Baird's tapir (Tapirus bairdii). For them, this species showed mostly crepuscular activity and diurnal activity in areas providing the animals with a highly protected habitat. In Mexico, Lira-Torres \& Briones-Salas (2012) found that in an area where subsistence hunting was practiced, T. bairdii presented nocturnal and crepuscular habits. It was suggested in a study by Cove et al. (2013) and supported in this study by the abundance of photographic records that an increase in human presence may compel a high number of infrequent species to move to and concentrate in areas that provide them with suitable habitat. This suggests that $T$. pinchaque might be concentrated in dense cover areas (SF) within the SFFOQ possibly to avoid human presence. Conditions in the SFFOQ may offer some protection to tapirs, but this species is losing high-quality habitats in larger protected areas near the SFFOQ most likely due to anthropic pressures.

Authors such as Cove et al. (2013) contend that species of the genus Tapirus are very sensitive to changes in their habitats. This may put them at risk as populations of large herbivores are among the first species to be threatened when their habitats deteriorate. Given the high conservation value of T. pinchaque, it is imperative to validate to what extent the SFFOQ provides this species protection or shelter, considering the pressures it endures. Conclusions by Cove et al. (2013) support this idea.

Cuniculus paca was present in well-conserved covers with little disturbance (SF and OF), coinciding with studies by Kays et al. (2009), Pinto de Sá Alves \& Andriolo (2005), Lira-Torres \& Briones-Salas (2012), and Gonthier \& Castañeda (2013). The first three studies classified it as a species of nocturnal activity patterns, in coincidence with our study, where we found a significant nocturnal activity pattern. For D. punctata we found a significant crepuscular and diurnal activity. Dasyprocta punctata and C. paca were recorded in the same covers (SF and $\mathrm{OF}$ ), the former during the day and the latter during the night. These species may be sympatric but their habits are different. Even though both rodents live in the same plant covers, they carry out their activities at different times of the day; therefore, they do not 
compete directly for resources. These activity patterns have also been reported by Kays et al. (2009) in Barro Colorado (Panamá) and by Jiménez et al. (2010) in Peruvian forests. Dasyprocta punctata is highly successful in tolerating anthropic interventions; because of its diurnal activities, it is frequently exposed to humans (Lira-Torres \& Briones-Salas 2012). The main author of this paper had evidence of this since he has sighted individuals of this species on the road that crosses the SFFOQ, on trails in the La Selva Biological Station and the Golfo Dulce Forest Reserve in Costa Rica (Jiménez 2001), as well as in urban areas in Santa Cruz de la Sierra (Bolivia).

Dasypus novemcinctus was the fourth most frequently photographed species. On the contrary, Monroy-Vilchis et al. (2010) and Gonthier \& Castañeda (2013) obtained limited photographs of this species; they attributed their results to the low sensitivity of camera traps due to the small size of these animals. Reports by other authors, such as Lira-Torres \& Briones-Salas (2012), described D. novemcinctus as an abundant species. The abundance of photographic records in their study was a result of the height at which the camera traps were placed (40 $\mathrm{cm}$ above ground). According to them, this increased the likelihood of detecting these small mammals. In this study, the cameras were placed $50 \mathrm{~cm}$ above the ground and slanted slightly downwards, possibly improving the detection of $D$. novemcinctus. It was recorded sometimes in pairs, and in habitats with and without anthropic intervention. This finding could indicate the high adaptability of D. novemcinctus similar to that found by Jiménez (2001) who reports a relative high abundance of this species in habitats with and without anthropic intervention in the Golfo Dulce Forest Reserve (Costa Rica).

Finally, most of the photographs were taken between 19:00 and 7:00 hours. During this period of night and early morning, the animals were mainly seeking food resources or foraging. This evidence supports Monroy-Vilchis et al. (2010), Lira-Torres \& BrionesSalas (2012), as well as Lynam et al. (2013) classification of neotropical large and medium-sized mammals as mostly nocturnal. However, at least two of the species reported here, $C$. thous and T. pinchaque, had significant crepuscular activity patterns too.

Our results show that two mammals in SFFOQ are threatened by humans and exotic species, and it is mandatory to minimize their interaction with these threats. This should impose greater control on the activity of humans in settlements in the vicinity of less-conserved habitats. It is necessary to separate well-conserved habitats from those where the human activity causes impacts.

\section{Conclusions}

Our study confirmed the presence of a community of large and medium-sized mammals, as a subset of the diversity of the Otún River basin and Colombian Central Andes. Two species identified here displayed changes in activity patterns, from diurnal to nocturnal, most likely as a result of the increased pressure generated by human activity. These preferences and changes are evident in the case of T. pinchaque, a species with conservation priority, which moved into SFFOQ well-conserved habitats. Also evidencing this situation is $C$. thous, a very adaptable species found in less-conserved habitats and tolerating the presence of domestic dogs. 


\section{Acknowledgments}

Authors thank Pontificia Universidad Javeriana and Centre for Research and Studies on Biodiversity and Genetic Resources (CIEBREG) for their funding (COLCIENCIAS Project Grant ID 002045) and logistic support during the research. Likewise, they thank the park rangers and staff at Otún Quimbaya Flora and Fauna Sanctuary for their accessibility, collaboration, and participation during the field phase of the study.

\section{Conflict of Interest Statement}

The authors declare that there are no conflicts of interest.

\section{References}

Abi-Said M, Amr Z. Camera trapping in assessing diversity of mammals in Jabal Moussa Biosphere Reserve, Lebanon, Vertebrate Zoology, 62(1): 145-152. 2012

Retrieved from: http://www.senckenberg.de/files/content/forschung/publikationen/ vertebratezoology/vz62-1/08_vertebrate_zoology_62-1_abi-said_145-152.pdf

Alberico M, Cadena A, Hernández-Camacho J, Muñoz-Saba Y. Mamíferos (Synapsida:Theria) de Colombia, Biota Colombiana, 1(1): 43-75, 2000

Arredondo DH. Plan de investigaciones del Santuario de fauna y flora Otún Quimbaya, Unidad Administrativa Especial del Sistema de Parques Nacionales Naturales, 96p. 2008.

Bonilla-Morales MM, Rodríguez Pulido J, Murillo Pacheco R. Biología de la lapa (Cuniculus paca Brisson): una perspectiva para la zoocría, Revista CES Medicina Veterinaria y Zootecnia, 8(1): 129-142, 2013

Bridges AS, Noss AJ. Behavior and Activity Patterns 57-68 En Camera Traps in Animal Ecology Methods and Analyses. Allan F. O'Connell, James D. Nichols K. Ullas Karanth (Editors). Springer Tokyo Dordrecht, Heidelberg, London, New York. 271p. 2011. doi: 10.1007/978-4-431-99495-4

Carbajal-Borges JP, Godínez-Gómez O, Mendoza E. Density, abundance and activity patterns of the endangered Tapirus bairdii in one of its last strongholds in southern Mexico, Tropical Conservation Science, 7(1): 100-114, 2014

Castellanos A. Andean bear home ranges in the Intag region, Ecuador, Ursus, 22(1): 65-73. 2011.

doi: 10.2192/ursus-d-10-00006.1

Colwell RK. EstimateS: Statistical estimation of species richness and shared species from samples. Version 7.52, 2009.

Retrieved from: http://purl.oclc.org/estimates

Cove MV, Spínola RM, Jackson VL, Sáenz JC, Chassot O. Integrating occupancy modeling and camera-trap data to estimate medium and large mammal detection and richness in a Central American biological corridor, Tropical Conservation Science, 6(6): 781-795, 2013.

Delgado CA, Zurc D. Diet of the Crab-eating fox Cerdocyon thous (Carnivora: Canidae) in the Páramo de Belmira, Antioquia, Colombia, Brenesia, 67: 73-74, 2007.

Gessner J, Buchwald R, Wittemyer G. Assessing species occurrence and species-specific use patterns of bais (forest clearings) in Central Africa with camera traps, African Journal of Ecology, 52: 59-68, 2013.

doi: $10.1111 /$ aje.12084 
Gonthier DJ, Castañeda FE. Large- and medium-sized mammal survey using camera traps in the Sikre River in the Río Plátano Biosphere Reserve, Honduras, Tropical Conservation Science, 6 (4): 584-591, 2013.

Guerrero LA, Moreno MA, Gallego E, Marín G, Walker R, Orozco FE, García O, López GR, Zamora M. Plan Básico de Manejo 2005- 2009, Santuario de Fauna y Flora Otún Quimbaya. Parques Nacionales Naturales de Colombia. Dirección Territorial Noroccidente. Medellín, Colombia. 159p. 2004.

Ilemin Y, Gürkan B. Status and activity patterns of the Caracal, Caracal caracal (Schreber, 1776), in Datça and Bozburun Peninsulas, Southwestern Turkey, Zoology in the Middle East, 50: 3-10, 2010.

doi: $10.1080 / 09397140.2010 .10638405$

Jackson RM, Roe JD, Wangchuk R, Hunter DO. Surveying Snow Leopard Populations with Emphasis on Camera Trapping: A Handbook. The Snow Leopard Conservancy, Sonoma, California. 73 p. 2005.

Jiménez CF, Quintana H, Pacheco V, Melton D, Torrealva J, Tello G. Camera trap survey of medium and large mammals in a montane rainforest of northern Peru, Revista peruana de Biología, 17(2): 191 - 196, 2010

Jiménez G. Propuesta metodológica para el diseño y validación de corredores biológicos en Costa Rica, Revista Forestal Centroamericana, 34: 73-79, 2001.

Retrieved from: http://www.ots.ac.cr/bnbt/22274.html

Kays R, Kranstauber B, Jansen PA, Carbone C, Rowcliffe M, Fountain T, Tilak S. Camera traps as sensor networks for monitoring animal communities. The 34th IEEE Conference on Local Computers Networks. 8p. 2009.

doi: $10.1109 / \operatorname{lcn} .2009 .5355046$

Kovach, W. L. Oriana circular statistics for Windows, ver. 4. Kovach Computing Services, Pentraeth, Wales, United Kingdom, 2011.

Laundré JW, Hernández L. Chapter 6 What We Know about Pumas in Latin America 76-90 In Cougar Ecology and Conservation Edited by Maurice Hornocker and Sharon Negri (Editors). The University of Chicago Press. Chicago and London. 306 p. 2009.

Lenth B, Knight RL, Brennan M. The effects of dogs on wildlife communities, Natural Areas Journal, 28(3): 218-227, 2008.

doi: 10.3375/0885-8608(2008)28[218:teodow]2.0.co;2

Lira-Torres I, Briones-Salas M. Abundancia relativa y patrones de actividad de los mamíferos de los Chimalapas, Oaxaca, México, Acta Zoológica Mexicana, 28(3): 566-585, 2012.

Lizcano D, Guarnizo A, Suárez J, Kaston F, Montenegro O. Danta de Paramo Tapirus pinchaque En: Rodriguez Mahecha, J.V., Alberico, M., Trujillo, F., Jprgeson, J. (Editores). Libro Rojo de los Mamíferos de Colombia. Serie Libros Rojos de Especies Amenazadas de Colombia. Conservación Internacional Colombia, Ministerio de Ambiente Vivienda y Desarrollo Territorial. Bogotá, Colombia. 433 p. 2006.

Lizcano D, Pizarro JV, Cavelier J, Carmona J. Geographic distribution and population size of the mountain tapir (Tapirus pinchaque) in Colombia, Journal of Biogeography, 29: 7-15, 2002.

doi: 10.1046/j.1365-2699.2002.00654.x

Lizcano D, Cavelier J. Densidad Poblacional y Disponibilidad de Hábitat de la Danta de Montaña (Tapirus pinchaque) en los Andes Centrales de Colombia, Biotropica, 32(1): 165-173, 2000.

doi: 10.1646/0006-3606(2000)032[0165:dpyddh]2.0.co;2 
Lynam AJ, Jenks KE, Tantipisanuh N, Chutipong W, Ngoprasert D, Gale GA, Steinmetz R, Sukmasuang R, Bhumpakphan N, Grassman LI, Cutter P, Kitamura S, Reed DH, Baker MC, McShea WJ, Songsasen N, Leimgruber Peter. Terrestrial Activity Patterns of Wild Cats from Camera-Trapping, Raffles Bulletin of Zoology, 61(1): 407-415, 2013

Macdonald DW, Sillero-Zubiri C. Dramatis personae 3-38 In Biology and Coservation of Wild Canids. D.W. Macdonald, C. Sillero-Zubiri (Eds), Oxford University Press, 450 p. 2004.

doi: 10.1093/acprof:oso/9780198515562.001.0001

Melo GL, Sponchiado J, Cáceres NC. Use of camera-traps in natural trails and shelters for the mammalian survey in the Atlantic Forest. Iheringia, Série Zoologia, Porto Alegre 102(1): 88-94, 2012

Michalski F, Crawshaw PG, Oliveira TG; Fabián ME. Notes on home range and habitat use of three small carnivore species in a disturbed vegetation mosaic of southeastern Brazil, Mammalia, 70(1/2): 52-57,2006

doi: $10.1515 / \mathrm{mamm} .70 .1-2.52$

Monroy-Vilchis O, Zarco-González MM, Rodríguez-Soto C, Soria-Díaz L, Urios V. Fototrampeo de mamíferos en la Sierra Nanchititla, México: abundancia relativa y patrón de actividad, Revista de Biología Tropical, Vol. 59 (1): 373-383, 2010.

doi: $10.15517 /$ rbt.v59i1.3206

Morales-Jiménez AL. Densidad de los monos aulladores (Alouatta seniculus) en un bosque subandino, Risaralda, Colombia, Neotropical Primates, 10(3): 141-144, 2002.

Ordeñana MA, Crooks KR, Boydston EE, Fisher RN, Lyren LM, Siudyla S, Haas CD, Harris S, Hathaway SA, Turschak GM, Miles AK, Van Vuren DH. Effects of urbanization on carnivore species distribution and richness, Journal of Mammalogy, 91(6): 1322-1331, 2010. http://www.bioone.org/doi/full/10.1644/09-MAMM-A-312.1

Osbahr K. Identificación de plantas consumidas por Agouti taczanowskii y Dinomys branickii a partir de fragmentos recuperados en heces, Revista U.D.C.A, Actualidad y Divulgación Cientifica, 2(2): 42-49, 1999.

Parques Nacionales Plan de manejo 2007 - 2011 Santuario de Fauna y Flora Otún-Quimbaya. Parques Nacionales Naturales de Colombia. Dirección Territorial Noroccidente Medellín. Antioquia. 30p. 2011

Pérez-Irineo G, Santos-Moreno A. Density, distribution, and activity of the ocelot Leopardus pardalis (Carnivora: Felidae) in Southeast Mexican rainforests, Revista de Biología Tropical, 62 (4): 1421-1432, 2014.

doi: $10.15517 /$ rbt.v62i4.12941

Pinto de Sá Alves LC, Andriolo A. Camera traps used on the mastofaunal survey of Araras Biological Reserve, IEF-RJ, Revista brasileira de Zoociências Juiz de Fora, 7(2): 231-246, 2005.

Ralls K, Pilgrim K, White PJ, Paxinos E, Schwartz M, Fleischer RC. Kinship, Social Relationships, and Den Sharing in Kit Foxes, Journal of Mammalogy 82 (3): 858-866, 2001. http://dx.doi.org/10.1644/1545-1542(2001)082<0858:KSRADS>2.0.CO;2

Ramírez A, Arredondo D, Zabaleta A, Ríos C, Walker R, López G. Programa de monitoreo del Santuario de fauna y flora Otún Quimbaya. Unidad Administrativa Especial del Sistema de Parques Nacionales Naturales. 66p. 2008.

Ramesh T, Kalle R, Sankar K, Qureshi Q. Activity pattern of Sloth Bear Melursus ursinus (Mammalia: Ursidae) in Mudumalai Tiger Reserve, Western Ghats, India, Journal of Threatened Taxa, 5(5): 3989-3992, 2013.

doi: 10.11609/jott.03071.3989-92 
Rocha VJ, Aguilar LM, Silva-Pereira JE, Moro-Rios RF, Passos FC. Feeding habits of the crab eating fox, Cerdocyon thous (Carnivora: Canidae), in a mosaic area with native an exotic vegetation in Southern Brazil, Revista Brasileira de Zoologia, 25(4): 594-600, 2008.

doi: 10.1590/s0101-81752008000400003

Rodríguez -Mahecha JV, Alberico M, Trujillo F, Jorgenson J (Eds.) Libro rojo de los mamíferos de Colombia. Serie Libros Rojos de Especies Amenazadas de Colombia. Conservación Internacional Colombia y Ministerio de Ambiente Vivienda y Desarrollo Territorial. Bogotá, Colombia 433p. 2006.

Saito M, Koike F. Distribution of Wild Mammal Assemblages along an Urban-Rural-Forest Landscape Gradient in Warm-Temperate East Asia, PLoS ONE, 8(5): e65464, 2013. doi: 10.1371/journal.pone.0065464

Salom-Perez R, Carrillo E, Saenz JC, Mora JM. Critical condition of the jaguar Panthera onca population in Corcovado National Park, Costa Rica, Oryx, 41(1): 51-56, 2007.

doi: $10.1017 / \mathrm{s} 0030605307001615$

Sánchez F, Sánchez-Palomino P, Cadena A. Inventario De Mamíferos En Un Bosque De Los Andes Centrales De Colombia, Caldasia, 26(1): 291-309, 2004.

Sathyakumar S, Bashir T, Bhattacharya T, Poudyal K. Assessing mammal distribution and abundance in intricate eastern Himalayan habitats of Khangchendzonga, Sikkim, India, Mammalia, 75:257-268, 2011.

doi: $10.1515 / \mathrm{mamm} .2011 .023$

Srbek-Araujo AC, Chiarello AG. Is camera-trapping an efficient method for surveying mammals in Neotropical forests? A case study in south-eastern Brazil, Journal of Tropical Ecology, 21 (1): 121-125, 2005.

doi: $10.1017 / \mathrm{S} 0266467404001956$

Sime, C. A. Domestic Dogs in Wildlife Habitats. Pages 8.1-8.17 in G. Joslin and H. Youmans, coordinators. Effects of recreation on Rocky Mountain wildlife: A Review for Montana. Committee on Effects of Recreation on Wildlife, Montana Chapter of The Wildlife Society. 307pp. 1999.

Springer MT, Carver AD, Nielsen CK, Correa NJ, Ashmore JR, Ashmore JR, Lee JG. Relative abundance of mammalian species in a central panamanian rainforest, Revista Latinoamericana de Conservación, 3(1): 19-26, 2012.

StatPoint Technologies. Statgraphics Centurion XVI. 2012

Tobler MW. CAMERA BASE Version 1.4User Guide. 32 p. 2010.

Retrieved from: http://www.atrium-biodiversity.org/tools/camerabase/

Tobler MW, Carrillo-Percastegui SE, Powell G. Habitat use, activity patterns and use of mineral licks by five species of ungulate in south-eastern Peru, Journal of Tropical Ecology, 25(3): 261-270, 2009.

doi: $10.1017 / \mathrm{s} 0266467409005896$

Tobler MW, Carrillo-Percastegui SE, Pitman RL, Mares R, Powell G. An evaluation of camera traps for inventorying large- and medium sized terrestrial rainforest mammals, Animal Conservation, 11:169-178, 2008.

doi: 10.1111/j.1469-1795.2008.00169.x

Torres PC, Prado PI. Domestic dogs in a fragmented landscape in the Brazilian Atlantic Forest: abundance, habitat use and caring by owners, Brazilian Journal of Biology, 70 (4): 987-994, 2010.

doi: 10.1590 / S1519-69842010000500010 
Walker S, Novaro A. Chapter 7 The World's Southernmost Pumas in Patagonia and the Southern Andes 91-99 En Cougar Ecology and Conservation Edited by Maurice Hornocker and Sharon Negri (Editors). The University of Chicago Press. Chicago and London. 306 p. 2009.

Yasuda M. Monitoring diversity and abundance of mammals with camera traps: a case study on Mount Tsukuba, central Japan, Mammal Study, 29(1): 37-46, 2004.

doi: $10.3106 /$ mammalstudy.29.37

\section{Programa de monitoreo de mamíferos en un área protegida de colombia}

Resumen. La información sobre los mamíferos de mediano y gran tamaño que habitan áreas protegidas en Colombia es cada vez más necesaria para impulsar acciones tendientes a su protección. La identificación completa de estas especies, sus números y sus patrones de actividad son esenciales en programas de monitoreo, especialmente por las relaciones entre estos animales y las dinámicas antropogénicas. El presente estudio se llevó a cabo en el Santuario de Flora y Fauna Otún-Quimbaya (Colombia). Entre el segundo semestre de 2009 y el primer semestre de 2011, se colocaron trampas cámara en áreas conservadas y perturbadas del Santuario de Flora y Fauna Otún-Quimbaya. Con un esfuerzo de muestreo de 2066 días-cámara se obtuvieron 673 fotografías de 157 eventos independientes para 8 especies silvestres y una doméstica. Los patrones de actividad observados fueron principalmente nocturnos, incluso para especies reportadas como diurnas. El impacto de la interferencia humana y de las especies exóticas fue evidente en 2 especies: Tapirus pinchaque y Cerdocyon thous. La primera fue observada por debajo de su rango altitudinal con patrones de actividad principalmente crepusculares y nocturnos. La segunda se observó en los mismos hábitats donde se encontraron los perros domésticos, con patrones de actividad principalmente crepusculares y nocturnos. Estos hallazgos sugieren que ambas especies han alterado sus patrones de actividad. Es necesario enfocar acciones en la disminución de la interacción de estos mamíferos con los humanos y con perros domésticos.

Palabras clave: diversidad de mamíferos; patrones de actividad; hábitats de cobertura vegetal; trampas cámara; Otún Quimbaya.

\section{Programa de monitoraçáo de mamíferos em uma área protegida em Colômbia}

Resumen. Entre o segundo semestre de 2009 e o primeiro semestre de 2011, câmeras foram armadas em habitats conservados e perturbados no Santuário de Flora e Fauna Otún Quimbaya. A partir de uma amostragem de 2066 dias de instalação da câmera, foram obtidas 673 fotografias de 157 eventos independentes para oito espécies de mamíferos selvagens e uma espécie doméstica. Os padrões de atividade observados eram principalmente noturnos, inclusive para espécies reportadas como diurnas. O impacto da interferência humana e de espécies exóticas foi observado para duas espécies: Tapirus pinchaque e Cerdocyon thous. A primeira foi observada abaixo de seu intervalo de altitude com padrões de atividade majoritariamente crepuscular e noturno. A segunda espécie foi observada nos mesmos habitats em que espécies de cachorros domésticos foram observados, com padrões de atividade majoritariamente crepuscular e noturno. Estes resultados sugerem que ambas as espécies alteraram seus comportamentos padrão. Ações devem ser focalizadas para reduzir a interação de estes mamíferos com os humanos e cães domésticos.

Palavras-chave: diversidade mamífera; padrões de comportamento; habitats com cobertura vegetal; armadilhas com câmeras; Otún Quimbaya. 


\section{Germán Jiménez}

Assistant professor in Biology Department and head of Wildlife Research Group. His research interests are in Wildlife Ecology Management, Conservation Biology and Complex Systems modelling and simulation.

\section{Natalia López-Cepeda}

Honorary member of Wildlife Research Group at Pontificia Universidad Javeriana. Her research interests are in camera trapping of medium and big size mammals.

\section{Andrea P Delgado}

Currently is honorary member of Wildlife Research Group at Pontificia Universidad Javeriana. Her research interests are in medium size mammals specially Dinomys branikii. She has been adviser for environmental areas of some enterprises.

\section{Ana M Guevara}

Currently is honorary member of Wildlife Research Group at Pontificia Universidad Javeriana. Her research interests are in medium and big size mammals prints specially to know relative abundance indexes.

\section{Laura Lozano}

Currently is honorary member of Wildlife Research Group at Pontificia Universidad Javeriana. Her research interests are in camera trapping of medium and big size mammals. 